\title{
Bear in Mind: Bear Hunting in the Mesolithic of the Southern Caucasus
}

\section{Citation}

Bar-Oz, Guy, Anna Belfer-Cohen, Tengiz Meshveliani, Nino Jakeli, Zinovi Matskevich, and Ofer Bar-Yosef. 2009. Bear in mind: Bear hunting in the Mesolithic of the southern Caucasus. Archaeology, Ethnology \& Anthropology of Eurasia 37(1): 15-24.

\section{Published Version}

doi:10.1016/j.aeae.2009.05.002

\section{Permanent link}

http://nrs.harvard.edu/urn-3:HUL.InstRepos:4270519

\section{Terms of Use}

This article was downloaded from Harvard University's DASH repository, and is made available under the terms and conditions applicable to Open Access Policy Articles, as set forth at http:// nrs.harvard.edu/urn-3:HUL.InstRepos:dash.current.terms-of-use\#OAP

\section{Share Your Story}

The Harvard community has made this article openly available.

Please share how this access benefits you. Submit a story.

Accessibility 


\section{Bear in Mind:}

\section{Bear Hunting in the Mesolithic of the Southern Caucasus}

\section{Guy Bar-Oz (Corresponding Author)}

Laboratory of Archaeozoology, Zinman Institute of Archaeology, University of Haifa, 31905 Haifa 31905, Israel; guybar@research.haifa.ac.il; fax: 972-4-8249-876

\section{Anna Belfer-Cohen}

Institute of Archaeology, Hebrew University, Jerusalem 91905, Israel;

belferac@mscc.huji.ac.il

\section{Tengiz Meshveliani}

Georgian State Museum, Department of Archaeology, Tbilisi 380007, The Republic of Georgia; tengo_m@caucasus.net

\section{Nino Jakeli}

Georgian State Museum, Department of Archaeology, Tbilisi 380007, The Republic of Georgia;

\section{Zinovi Matskevich}

Department of Anthropology, Peabody Museum, Harvard University, Cambridge, MA 02138,USA; matskev@fas.harvard.edu

\section{Ofer Bar-Yosef}

Department of Anthropology, Peabody Museum, Harvard University, Cambridge, MA 02138,USA; obaryos@,fas.harvard.edu

Please cite as: Bar-Oz, G., Belfer-Cohen., Meshveliani, T., Jakeli, N., Matskevich, Z. and Bar-Yosef, O. 2008. Bear in mind: bear hunting in the Mesolithic of the southern Caucasus. Archaeology, Ethnology and Anthropology of Eurasia, in press. 


\begin{abstract}
We present new faunal data from Kotias Klde rockshelter, Republic of Georgia, where a substantial part of the faunal assemblage consists of brown bear remains (Ursus arctos) found in clear association with Mesolithic artifacts. Bear remains are unusually well represented compared to other faunal assemblages from the Caucasus and Eurasia in general. Species diversity, dominance of young individuals, full representation of skeletal elements and skinning butchery marks indicate that bears were actively hunted. Such a hunting endeavor denotes the complex network of relationships that linked the Mesolithic hunting societies with the animal world surrounding them.
\end{abstract}




\section{Introduction}

The regular hunting episodes throughout the Middle, Upper Palaeolithic and Mesolithic across Eurasia involved the acquisition of large prime-age herbivorous prey. Skilled hunting requires detailed knowledge on 'when' and 'where' to ambush or intercept specific animal game, and how to track, trap or capture it. A successful hunt ends in killing, butchering, and consuming the prey. The modes of hunting and butchering of certain species can vary culturally, chronologically and geographically, but they may also share some fundamental similarities in treatment and processing of carcasses.

The daily livelihood of hunters often required frequent encounters with wild animals, some of which displayed fierce defense tactics. However, it is only in later prehistoric periods that hunters started to pursue dangerous carnivore species (e.g., Klein, 2000). Such endeavors involved the hunting of the brown bear (Ursus arctos), apparently an activity imbued with special meaning for hunters of all cultures in the northern boreal zone of the globe. Ethnographic literature enumerates a broad range of ceremonial activities designed to honor and respect the bear (e.g., Hallowell, 1926). These studies signify that bears have never been hunted for their meat or fur; conversely, the importance of bear hunting lies primarily and foremost in its symbolism.

The great reverence with which brown bears are treated is deeply rooted in the ritual tradition of indigenous societies. One of the most elaborate rituals for many native Siberian people was the feast that followed a successful bear hunt. Carried in procession back to the village, the dead bear was offered food and drink and entertained with songs and dances for several days. Following the celebration the bear body was respectfully butchered and eaten, and its cleaned skull was set on a 
pole as a guardian totem (Zolotarev, 1937). Also, the word for a Siberian womanshaman is the same as the word for bear (Reid, 2002). Another notable ceremony that involves cultic sacrifice of bears is found among the Ainu people of Japan. For the Ainu the bear symbolized the god of mountains and forests and its hunting was followed by a ritual feast that involved eating the bear's meat and drinking its blood (Hiroshi, 1992). The bear feasts of native Lapps proclaim its hunting as partly ceremonious and Lapp shamans transform themselves into bears (dressed up and wearing masks) when they drum during religious ceremonies (Gjessing, 1947).

Archaeological data supply ample evidence for the particular importance of bear to Palaeolithic people and demonstrate that bears received special attention in spiritual beliefs and ritual behaviors in prehistoric times. Bears are always part of the carnivore scenery in Palaeolithic paintings located in seemingly pre-ordained places in caves, and most bear representations are associated with apparent hunting scenes (e.g., Chauvet, Deschamps, Hillaire, 1996; Morel, Garcia, 2002; Rouzaud, 2002 and references therein). A bear figurine made of mammoth ivory was also found at the Aurignacian of the Swabian Jura in southwest Germany (Conard, 2003). One of the most remarkable artistic representations in this connection is a headless clay (lifesize) modeling of a bear found in the interior part of the Magdalenian cave of Montespan in the French Pyrenees (Begouën, Casteret, Capitan, 1923; reviewed in Kurtén, 1976). It represents a reclining bear with a real bear skull between its forepaws that most probably had once been attached to the sculpture itself. The sculpture is punctured by spear marks, probably thrown during ritual ceremonies. The peculiar engraving of a bear in the Magdalenian cave of Trois-Freres, Ariege, France (Morel, Garcia, 2002), represents another example of the ritual significance of bears 
to Palaeolithic people. This bear seems to be vomiting blood and there are various markings on its body, perhaps representing spear and projectile wounds.

While bear skeletal remains and stone artifacts often occur in Eurasian Palaeolithic cave deposits from the Middle Palaeolithic onward, their association in many cases is not clear-cut and in most cases appear to represent separate accumulation episodes (Kurtén, 1958, 1976; Chase, 1987; Stiner, 1994; Stiner, Arsebük, Howell, 1996; Baryshnikov, 1997; Stiner, 1998; Tillet, 2002). Such a case was also reported in western Georgia where several partial (only the upper body and forelimbs) cave bear skeletons were found in a cave devoid of anthropogenic remains. Yet the cave is located in close proximity (as part of a cavernous system) to Middle Palaeolithic cave sites (Bronze Cave; Tushabramishvili, 1978). Also at Djruchula Cave the dominant species represented are cave bears (Tushabramishvili, 1978; see also Adler, Tushabramashvili, 2004). While there are distinct cases where bear (predominantly the extinct European cave bear, Ursus spelaeus and Ursus deningeri) skulls and perhaps other skeletal parts were intentionally collected by Palaeolithic people, direct archaeological evidence for bear hunting remains a rare phenomenon. In most cases the mortality profiles of bear remains found in archaeological cave sites represent immature and aged individuals which died during hibernation (e.g., Kurtén, 1958; Gargett, 1996; Stiner, 1998; Lord, O'Connor, Siebrandt, Jacobi, 2007). Another conceivable cause for the accumulation of predominantly young and old adult bear specimens in cave deposits might be due to transportation of bones by large carnivores or scavengers (e.g., Gargett, 1996; Niven, 2006; Argenti, Mazza, 2006). In other cases the occasional appearance of young adult bears might suggest that bears died from falling into natural traps in caves (Wolverton, 2001, 2006). It is only in rare cases that Upper Palaeolithic and Mesolithic faunal assemblages contain single 
specimens of brown bears that were most likely hunted. These bear remains were found in clear association with anthropogenic refuse, and some were bearing butchery marks (Bárta, 1989; Stiner, 1994; see also Chaix Bridault, Picavet, 1997). Such finds most probably derived either from attacking hibernating bears or from hunting encounters. Evidence for the killing of bear outside the hibernating season is crucial to recognizing active hunting activities of past foragers.

It is from this viewpoint that we examine new faunal data from Kotias Klde rockshelter, western Georgia, where a substantial part of the Mesolithic faunal assemblage consists of brown bear remains found in clear stratigraphic and spatial association with Mesolithic artifacts (Meshveliani et al., 2008). Bear remains here are unusually well represented compared to other faunal assemblages from the Caucasus and Eurasia in general. Species diversity of the assemblage, together with information about the age structure, proportional representation of skeletal elements and bone modification of the main represented taxa are used to determine the depositional history of the Mesolithic bone assemblage at the site

\section{Kotias Klde}

Kotias Klde is a karstic rockshelter within the limestone Mandaeti plateau, south of the Kvirila River and about $1 \mathrm{~km}$ from its tributary, the Sadzali Khevi, approximately 700 meters above sea level (Figure 1). From the back of the rockshelter there is an entrance to a narrow corridor-like cave that splits into diverging cavities as yet have not been explored or mapped.

The excavations at the rockshekter, in nine square meters at the entrance of cave, revealed a sequence of Neolithic, Mesolithic and Upper Palaeolithic levels (2003-2005 seasons; Meshveliani et al., 2008). The current study presents the 
findings from the Mesolithic layers (ca. dated to 12.4-10.3 ka cal BP by four charcoal samples). The Mesolithic human occupations are confined within dark clay sediments which attained a maximum thickness of ca. 60 centimeters. This deposit is rich in lithic and faunal material. All of the excavated sediments were systematically collected and wet-sieved through $2 \mathrm{~mm}$ mesh and the dry sediments were hand-picked for small bones and lithics. The material remains were processed according to their spatial and stratigraphic locations.

The lithic industry was produced by detachment of uni-directional blades and flakes, most of which were manufactured not at the site. The microlithic nature of the assemblage is demonstrated by the proliferation of varieties of backed and retouched bladelets including the obliquely truncated types. The distinctive tool types of this Mesolithic industry are the scalene and isosceles triangles, shaped mostly by bi-polar retouch from blades and bladelets. In several cases the truncation on the shorter plane is done on the proximal part of the object (Meshveliani et al., 2008).

\section{Faunal analysis procedure}

The bone sample analyzed includes only faunal remains that originated from the well defined Mesolithic contexts. Zooarchaeological and taphonomic coding procedures used to collect and evaluate the faunal data are published elsewhere (Bar-Oz, Adler, 2005; see also Bar-Oz, 2004 and Bar-Oz, Munro, 2004). Each excavation unit was treated separately and recorded stratigraphically. Skeletal elements and broad taxonomic identifications were carried out in the field using a virtual comparative collection of recent skeletons and osteological catalogues (Schmid, 1972; Hilson, 1999). Identifiable bones included articular ends and shafts of long bones, teeth, cranial fragments, carpals, tarsals, appendicular elements and vertebrae which were 
assigned to the most discriminating taxonomic level. Finer taxonomic identifications of closely related species were achieved with the assistance of A. Vekua from the Georgian State Museum and the comparative collection of the Georgian State Museum.

The separation of brown bear (Ursus arctos) from cave bear (Ursus spelaeus and Ursus deningeri) was based on morphological and size criteria of selected bones following Kurtén (1958) and Stiner (1998; Stiner et al., 1998). Skeletal elements that could not be assigned to species were grouped according to body-size classes. This applies to many of the bear and wild boar remains that were combined in a Sus/Ursus category. This category was easily distinguishable from red deer (Cervus elaphus) specimens which were much larger than those of either bear or boar.

Shaft fragments were coded according to the presence of specific zones (i.e., proximal shaft, mid-shaft or distal shaft) or diagnostic features (e.g., foramen muscle attachment, following the protocol of Stiner, 2004) and other morphological criteria of the shaft fragments (e.g., Barba, Dominguez-Rodrigo, 2005). In most cases identified specimens were coded according to their fraction of completeness (following Marean, 1991). Frequencies of element portions were used to calculate the minimum number of skeletal elements (MNE) and the minimum number of individuals (MNI) (following Grayson, 1984; Klein, Cruz-Uribe, 1984; Lyman, 1994; O'Connor, 2000). The number of identified specimens (NISP) was used as a basic measure of taxonomic abundance (Grayson, 1984).

Recorded elements were examined for macroscopic surface modifications using a low-resolution magnifying lens (x2.5). We observed modifications induced by humans (butchery, burning, and bone fragmentation), animals (rodent gnawing or carnivore puncture, scoring and digestion) and post-depositional attrition agents 
(weathering, trampling, bleaching, abrasion and root activity) (e.g., Behrensmeyer, 1978; Binford, 1981; Villa, Mahieu, 1991; Lyman, 1994; Bar-Oz, Dayan, 2003). The morphology of limb shaft fracture planes was analyzed for bone fragments bearing ancient fractures. Fracture angle and fracture outline were assessed in order to determine the condition which the bone was in when fractured, i.e. fresh versus dry (see Villa, Mahieu, 1991 for a detailed typological description of the fractures). The degree of completeness of the long bone shaft circumference was recorded (i.e., complete, more than half, or less than half of the complete circumference) in order to discern the role of bone marrow extraction (following Bunn, 1983).

The age structure of bear and wild boar was defined on the basis of epiphyseal fusion of long bones and dental eruption and wear of the deciduous fourth premolar (dP4) and the third molar (M3) (data for bear - Stiner, 1998; for wild boar - Bull and Payne, 1982, Grant, 1982). Each bear tooth was assigned to one of nine wear stages using Stiner's (1998:312-313) wear-scale illustrations. Specimens were clustered into four major age categories: 'neonatal', 'juvenile', 'adult' and 'old adult'. The 'neonatal' group includes bones that by size and texture are of near-born fetuses or recently-born young. The 'juvenile' group includes specimens with unfused long bones, in which fusion occurs by the age of 24 months, and deciduous tooth and/or the permanent counterpart with no wear (stages I-III of Stiner's, 1988 wear scheme). The 'adult' category comprises successive categories of occlusal wear (stage IV-VII) and fused bones, and the 'old adult' category is defined by teeth with heavy wear (stages VIII-IX).

\section{The faunal assemblage}


A total of 775 complete and fragmentary bone elements were identified to taxon (including bone elements identified only to body-size group, Table 1). The majority of bones are of wild boar (Sus scrofa) and brown bear (Ursus arctos), constituting more than $75 \%$ of Kotias Klde assemblage (Appendix). Both the boar and the bear bones derive each from at least four different individuals and none of the bones was found in articulation. Their remains were evenly dispersed across the Mesolithic horizontal stratum and were mixed with the remains of other taxa. Various ungulates are represented in relatively low proportions and include roe deer (Capreolus capreolus, $7.6 \%$ of total NISP) and red deer (Cervus elaphus, 7.5\%). Additional carnivore species include pine marten (Martes martes), wolf (Canis sp.) and fox (Vulpes vulpes).

The Mesolithic bone assemblage of Kotias Klde exhibits excellent preservation conditions condition as evidenced by the presence of the whole range of bone densities, including porous parts such as sternum fragments. Bone preservation does not seem to vary among taxa (Table 2). The long bones show no significant signs of surface weathering (i.e., higher then weathering stage 1 of Behrensmeyer's [1978] 6 weathering stages scheme), indicating rapid burial of finds within the rockshelter deposits. Also, traces of carnivore ravaging are few (only three cases were noted on bear bones, gnawing on distal metatarsus, tooth puncture on a second phalanx and a digested first phalanx) as are signs of rodent gnawing. Root marks are scarce and there are no bleached or abraded bones. The only difference in bone preservation among taxa is the rate of shaft fragmentation among marrow bearing long-bones (NISP:MNE). This ratio is lowest for the bear long bones, indicating that bear bones are more complete and less fragmented than those of other taxa represented. This is also evident by the rate of long bone shaft circumference. The 
completeness of bear shaft circumferences is higher than that of ungulates in the assemblage. This data could indicate that bear long bones were not extensively broken as those of other ungulates. It could suggest that in contrast to the ungulate the bear bones were not split open for their marrow. Still both taxa represented show relatively equal ratios of long bones with fresh fractures, indicating that the majority of bones were broken while the bones were still green.

Butchery marks appear in low numbers; however their anatomic locations on the red deer and boar remains represent virtually all stages of carcass processing, including skinning (distal metapod of red deer) and dismembering of the carcass (single mark on a proximal rib; on a distal femur of boar; distal humerus and scapula glenoid-fossa of red deer), as well as filleting meat from the bones (two marks on rib shafts and one on medial-shaft of boar femur). The wild boar bones, the largest prey category, comprise all skeletal elements (Figure 2) and exhibit butchery marks from major stages of slaughtering. This could suggest that their carcasses underwent thorough dismemberment and preparation on site. Yet the number of burnt bones is rather small, mostly on limb distal ends (nine phalanges and two distal metapodia), perhaps suggesting that the boar limbs were roasted before filleting.

The bear remains include three butchery marks that were found on three distal metatarsi. Such a butchery mark is consistent with a circular cut to separate the paws from the fur (Binford, 1981), most probably made during skinning of the carcass. Burnt bones are evident only among feet specimens. These include four phalanges (three first and a single second phalanges) and a single distal metapod. While the assemblage is too small to reconstruct a detailed skeletal elements profile, it appears that all skeletal elements are represented (Figures 2, 3). Thus it seems reasonable to conclude that entire bear carcasses were transported to the site. 
While roe and red deer are represented solely by adult individuals (12 and 10 fully fused long bones; Table 3), the wild boar remains are dominated by a high number of young individuals (approximately 50\% are under the age of 24 months) and neonatal piglets (about 10\%, Table 3). The size of the neonates suggests that some were less than three months old when killed (Amorosi, 1989). Assuming that wild boar in the Caucasus give birth their young in early spring (March-April; Heptner et al., 1989) the Kotias Klde remains represent animals killed during late spring-early summer. Teeth wear and bone fusion of brown bear remains reveal that the majority derive from adult individuals (Table 3 ). Several unfused bones indicate the presence of at least one young individual.

\section{Discussion}

The Mesolithic faunal assemblage of Kotias Klde rockshelter represents repeated seasonal visits by hunters targeting mainly wild boar and bear. The abundance of piglets and the fact that bear remains were an integral part of the bone refuse indicate that hunting episodes took place during the late spring-early summer. This implies that bears were actively hunted rather than slaughtered while hibernating. This observation is also supported by the demographic profile of the bears killed. The setting of Kotias Klde of the Mesolithic stratum in the middle of the rockshelter's entrance further indicates that the bear assemblage, which includes adult individuals, could not have been created from natural trap capture of bears (Wolverton, 2001, 2006).

Compared with Middle and Upper Palaeolithic faunal assemblages from the region, dominated by Caucasian tur (Capra caucasica) and steppe bison (Bison priscus) (e.g., the assemblages from Ortvale-Klde rockshelter and Dzudzuana cave; 
Bar-Oz, Adler, 2005, Adler et al., 2006, Bar-Oz et al., 2008), the Kotias Klde assemblage displays a different suite of taxa dominated by dangerous prey such as wild boar and bear. The Mesolithic deposit from Darkveti rockshelter (Nebieridze 1978), located a few kilometers away in the Kvirila river gorge, contains the only similar (but much smaller) faunal assemblage within the region.

Brown bear is known from numerous Eurasian Mesolithic sites, normally represented by a few bones in each site (reviewed in Sommer and Benecke, 2005). However, at Kotias Klde the brown bear is one of the dominant prey taxa.

Though skinning marks may indicate that bear were hunted for their fur (Charles, 1997), it is reasonable to infer that the ultimate reason behind bear hunting was different. Bear hunting offers a challenge for the hunter and enables him to prove his hunting skills. These challenges were most probably interwoven with the mythological and ideational dimensions of bear within Mesolithic societies. The mythological role of bear is apparent in the complex beliefs and practices of indigenous boreal people, some of which were discussed above (Hallowell, 1926; Edsman, 1987; Janhunen, 2003). While the evidence from Kotias Klde may mirror these beliefs and practices, it is difficult to affirm whether the bear remains represent ritual killings such as those documented at bear festivals in various Eurasian societies. Also, the shift in the assortment of hunted game from the Upper Palaeolithic period to the Mesolithic may indicate the availability of new hunting tools and perhaps a new organizational strategy that allowed the targeting of dangerous prey. Though we have found no distinct evidence for use of bow or large spear heads, it is possible that the geometric flint tools found (mainly scalene triangles) were used in composite arrows. Ultimately the targeting of dangerous prey at Kotias Klde, such as wild boar and bear, must have been based on considerable skill and courage. Killing 
young wild boar meant facing their protective, ferocious mothers. The same dangers are heightened when facing hungry and belligerent bears emerging from the forests following the hibernation season. As such encounters likely occurred at close quarters, they tested one's courage and skill; these hunting patterns may represent rites of passage or initiation of young individuals as full fledged members of a hunting society. Ethnographic data support this notion. For example, similar hunting rites were practiced by the Orochi people of Siberia who used to hunt bear with a wooden shaft surmounted by a blade (Hallowell, 1926; Reid, 2002). This was an extremely dangerous undertaking as the spear had to be thrust into the animal's heart from close quarters. Similarly, some other Siberian tribes (e.g., Khant) used to practice hunting rites in which bears were tackled with knives (Reid, 2002). The hunter's left hand was thickly swathed, while his right hand held a long blade.

If the hunting of dangerous prey at Kotias Klde was motivated by ideological considerations it may explain why there was little or no exploitation of bear bone marrow as opposed to other ungulates. Alternatively, the Mesolithic hunters of Kotias Klde, with their intimate knowledge of the animals they exploited, knew that there was little marrow available for extraction following the long hibernation period.

We suggest that the exploitation of bears in the Caucasus Mesolithic can be viewed as part of the complex network of relationships that linked Mesolithic hunting societies with the animal world surrounding them. One may see a link between the activities that took place in Kotias Klde and the beginning of long lasting ceremonial bear hunting and cultic traditions that are strongly rooted and widespread to this very day among the hunting societies of indigenous boreal people.

\section{Acknowledgments}


We thank the American School for Prehistoric Research (Peabody Museum, Harvard University) for the financial support of this project. We are grateful to our colleagues at the Georgia State Museum: D. Lordkipanidze, A. Vekua, N. Tushabramishvili, for their collaboration and assistance during our research in the Republic of Georgia. Thanks are due to Reuven Yeshurun (University of Haifa) for taking part in the excavations and the laboratory analysis during fieldwork in 2005-2006 and to Dan Adler and Reuven Yeshurun for their thoughtful comments on earlier drafts. 


\section{$\underline{\text { Literature cited }}$}

Adler D.S., Bar-Oz, G., Belfer-Cohen, A., Bar-Yosef, O. 2006

Ahead of the Game: Middle and Upper Palaeolithic Hunting Behaviors in the

Southern Caucasus. Current Anthropology, vol. 47: 89 - 118.

\section{Adler D.S., Tushabramishvili N. 2004}

Middle Palaeolithic Patterns of Settlement and Subsistence in the Southern Caucasus. In Settlement Dynamics of the Middle Palaeolithic and Middle Stone Age, N. Conar ed.). Tübingen: Kerns Verlag (Publications in Prehistory), pp. 91 - 132.

\section{Amorosi T. 1989}

A Postcranial Guide to Domestic Neo-Natal and Juvenile Mammals -The Identification and Aging of Old World Species. Oxford: BAR International Series 533 (380 p.).

\section{Argenti P., Mazza P.P.A. 2006}

Mortality analysis of the Late Pleistocene bears from Grotta Lattaia, central Italy. Journal of Archaeological Science, vol. 33: 1552 - 1558.

\section{Barba R., Dominguez-Rodrigo M. 2005}

The Taphonomic Relevance of the Analysis of Bovid Long Limb Bone Shaft Features and their Application to Element Identification: Study of Bone Thickness and Morphology of the Medullary Cavity. Journal of Taphonomy, vol. 3: 29 - 42.

Baryshnikov G. 1997 
Cave Bears from the Paleolithic of the Greater Caucasus. In Quaternary Paleozoology in the Northern Hemisphere, J.J. Saunders, B.W. Styles, G. Baryshnikov (eds.). Springfield: Scientific Papers of the Illinois State Museum, pp. $69-118$.

\section{Bar-Oz G. 2004}

Epipalaeolithic Subsistence Strategies in the Levant: A Zooarchaeological Perspective. Cambridge: The American School of Prehistoric Research (ASPR) Monograph Series, Brill Academic Publishers Inc (154 p.).

\section{Bar-Oz G., Adler D.S. 2005}

Taphonomic History of the Middle and Upper Palaeolithic Faunal Assemblage from Ortvale Klde, Georgian Republic. Journal of Taphonomy, vol. 3: 185 - 211.

\section{Bar-Oz G., Dayan T. 2003}

Testing the Use of Multivariate Intersite Taphonomic Comparisons: The Faunal Analysis of Hefzibah In Its Epipalaeolithic Cultural Context. Journal of Archaeological Science, vol. 30: 885 - 900.

\section{Bar-Oz G., Munro N.D. 2004}

Beyond Cautionary Tales: A Multidimensional Taphonomic Approach for Identifying Subpatterns in Ungulate Body-Part Data. Journal of Taphonomy, vol. 2: 201 - 20.

\section{Bar-Oz G., Belfer-Cohen A., Meshveliani, T. Jakeli, N., Bar-Yosef, O. 2008}

Taphonomy and Zooarchaeology of the Upper Palaeolithic Cave of Dzudzuana, Republic of Georgia. International Journal of Osteoarchaeology, vol. 17: 1 - 21. 
Bárta J. 1989

Hunting of Brown Bears in the Mesolithic: Evidence from the Medvedia Cave Near Ruzínin Slovakia. In The Mesolithic in Europe, C. Bonsall (ed.). Edinburgh: John Donald, pp. 456-60.

\section{Begouën H., Casteret N., Capitan L. 1923}

La Caverne de Montespan. Revue Anthropologique, vol. 33: 333 - 50.

\section{Behrensmeyer A.K. 1978}

Taphonomic and Ecological Information from Bone Weathering. Paleobiology, vol. 4: $150-162$.

\section{Binford L.R. 1981}

Bones: Ancient Men and Modern Myths. New York: Academic Press (320 p.).

\section{Bull G., Payne S. 1982}

Tooth Eruption and Epiphysial Fusion in Pigs and Wild Boar. In Ageing and Sexing Animal Bones from Archaeological Sites, B. Wilson, C. Grigson, S. Payne (eds.). Oxford: BAR International Series 109, pp 55-71.

\section{Bunn H.T. 1983}

Evidence on the Diet and Subsistence Patterns of Plio-Pleistocene Hominids at Koobi Fora, Kenya, and Olduvai Gorge, Tanzania. In Animals and Archaeology 1: Hunters 
and Their Prey, J. Clutton-Brock, C. Grigson (eds.). Oxford: British Archaeological Report , pp 21-30.

Chaix L., Bridault A., Picavet R. 1997

A Tamed Brown Bear (Ursus arctos L.) of the Late Mesolithic from La GrandeRivoire (Ise`re, France)? Journal of Archaeological Science, vol. 24: 1067 - 74.

\section{Charles R. 1997}

The Exploitation of Carnivores and Other Fur-Bearing Mammals During the NorthWestern European Late Upper Palaeolithic and Mesolithic. Oxford Journal of Archaeology, vol. 16: $253-277$.

\section{Chase P. 1987}

The Cult of the Cave Bear. Expedition, vol. 29: 4 - 9 .

\section{Cauvet J.-M., Deschamps E.B., Hillaire C. 1996}

Dawn of Art: The Chauvet Cave. New York: Harry N. Abrams (135 p.).

\section{Conard N.J. 2003}

Palaeolithic Ivory Sculptures from Southwestern Germany and the Origin of Figurative Art. Nature, vol. 426: 830 - 833.

\section{Edsman C.-M. 1987}

Bears. In The Encyclopedia of Religion 2, M. Eliade (ed.). New York: Macmillan, pp. $86-89$. 


\section{Gargett R.H. 1996.}

Cave Bears and Modern Human Origins: The Spatial Taphonomy of Pod Hradem Cave, Czech Republic. Lanham, MD: University Press of America (265 p.).

\section{Gjessing G. 1947}

Norwegian Contributions to Lapp Ethnography. Journal of the Royal Anthropological Institute of Great Britain and Ireland, vol. 77: 47 - 60.

\section{Grant A. 1982}

The Use of Tooth Wear as a Guide to the Age of Domestic Ungulates. In Ageing and Sexing Animal Bones from Archaeological Sites, B. Wilson, C. Grigson, S. Payne (eds.). Oxford: BAR International Series 109, pp. $91-108$.

\section{Grayson D.K. 1984}

Quantitative Zooarchaeology. New York: Academic Press (202 p.).

\section{Hallowell I.A. 1926}

Bear Ceremonialism in the Northern Hemisphere. American Anthropologist, vol. 28: $1-175$.

\section{Heptner V.G., Nasimovich A.A., Banninkov A.G. 1989}

Mammals of the Soviet Union, vol. 1: Ungulates. Leiden: E. J. Brill (540 p.).

\section{Hillson S. 1999}


Mammal Bones and Teeth: an Introductory Guide to Methods of Identification.

London: Institute of Archaeology, University College London (64 p.).

\section{Hiroshi U. 1992}

The "Sending-Back" Rite in Ainu Culture. Japanese Journal of Religious Stuhes, vol.

19: $255-70$.

\section{Janhunen J. 2003}

Tracing the Bear Myth in Northeast Asia. Acta Slavica Iaponica, vol. 38: 1 - 24.

\section{Klein R.G. 2000}

Archeology and the Evolution of Human Behavior. Evolutionary Anthropology, vol. $17: 17-36$.

Klein R.G., Cruz-Uribe K. 1984

The Analysis of Animal Bones from Archaeological Sites. Chicago: University Chicago Press (266 p.).

\section{Kurtén B. 1958}

Life and Death of the Pleistocene Cave Bear: A Study in Paleoecology. Acta Zoologica Fennica, vol. 95: 4-59.

\section{Kurtén B. 1976}

The Cave Bear Story. New York: Colombia University Press (163 p.). 
Lord T.C., O'Connor T.P., Siebrandt D.C., Jacobi R.M. 2007

People and Large Carnivores as Biostratinomic Agents in Late Glacial Cave Assemblages. Journal of Quaternary Science, vol. 22: 681 - 694.

Lyman R.L. 1994

Vertebrate Taphonomy. Cambridge: Cambridge University Press (524 p.).

Marean C.W. 1991

Measuring the Postdepositional Destruction of Bone in Archaeological Assemblages. Journal of Archaeological Science, vol. 18: 677 - 694.

Meshveliani T., Bar-Oz G., Bar-Yosef O., Belfer-Cohen A., Boaretto E., Jakeli N. Koridze I.,. Matskevich Z. 2008.

Mesolithic Hunters at Kotias Klde, Western Georgia. Paléorient, in press.

Morel P., Garcia M.-A. 2002

La Chasse a l'ours dans A'art Paleolithique. In L'ours et L'homme, T. Tillet, L. R.

Binford (eds.). Liège: Etudes et Recherches Archéologique de l'Univesité de Liège, pp. $219-28$.

\section{Nebieridze L. 1978}

Darkvetis Mravalpeniani Ekhi (The Darkveti Multilayer Rockshelter). Tbilisi: Metsniereba (103 p.).

Niven L. 2006. 
The Palaeolithic Occupation of Vogelherd Cave: Implications for the Subsistence Behavior of Late Neanderthals and Early Modern Humans. Tübingen: Kerns Verlag (312 p.).

O'Connor T.P. 2000.

The Archaeology of Animal Bones. Texas: A\&M University Anthropology Series (206 p.).

Reid A. 2002

The Shaman's Coat: A Native History of Siberia. New York: Walker and Company (226 p.).

\section{Rouzaud F. 2002}

L'ours dans L'art Paleolithique. In L'ours et L'homme, T. Tillet, L.R. Binford (eds.). Liège: Etudes et Recherches Archéologique de l'Univesité de Liège, pp. 201 - 18.

\section{Schmid E. 1972}

Atlas of Animal Bones for Prehistorians, Archaeologists and Quaternary Geologists. Amsterdam: Elsevier Publishing Company (159 p.).

\section{Sommer R.S., Benecke N. 2005}

The Recolonization of Europe by Brown Bears Ursus arctos Linnaeus, 1758 After the Last Glacial Maximum. Mammal Review, vol. 35: 156 - 64.

Stiner M.C. 1994 
Honor among Thieves: A Zoo-archaeological Study of Neandertal Ecology.

Princeton, NJ: Princeton University Press (447 p.).

Stiner M.C. 1998

Mortality Analysis of Pleistocene Bears and Its Paleoanthropological Relevance.

Journal of Human Evolution, vol. 34: 303 - 26.

Stiner M.C. 2004

A Comparison of Photon Densitometry and Computed Tomography Parameters of Bone Density in Ungulate Body Part Profiles. Journal of Taphonomy, vol. 2: 117 146.

Stiner M.C., Arsebük, G., Howell F.C. 1996

Cave Bears and Paleolithic Artefacts in Yarimburgaz Cave, Turkey: Dissecting A Palimpsest. Geoarchaeology, vol. 11: $279-327$.

Stiner M.C., Achyuthan H., Arsebük G., Howell F.C., Josephonc S., Juell K.E., Pigati J., Quade J. 1998.

Reconstructing Cave Bear Paleoecology from Skeletons: A Cross-Discplinary Study of Middle Pleistocene Bears from Yarimbrugaz Cave, Turkey. Plaeobiology, vol. 24: $74-98$.

Tillet T. 2002 
Les Grottes a Ours et Occupations Neandertaliennes dans les Alps. In L'ours et L'homme, T. Tillet, L.R. Binford (eds.). Liège: Etudes et Recherches Archéologique de l'Univesité de Liège, pp. 167-84.

\section{Tushabramishvili D.M. 1978}

Arkheologicheskie Pamyatniki Tsutskhvatskogo Mnogoetajnogo Peshernogo Kompleksa (Archaeological Sites of the Tsutskhvati Cave Complex). Tbilisi:

Metsniereba (141 p.).

\section{Villa P., Mahieu E. 1991}

Breakage Patterns of Human Long Bones. Journal of Human Evolution, vol. 21: 27 48.

\section{Wolverton S. 2001}

Caves, Ursids, and Artifacts: A Natural-Trap Hypothesis. Journal of Ethnobiology, vol. $21: 55-72$.

\section{Wolverton S. 2006}

Natural-Trap Ursid Mortality and the Kurten Response. Journal of Human Evolution, vol. $50: 540-551$.

\section{Zolotarev A.M. 1937}

The Bear Festival of the Olcha. American Anthropologist, vol. 39: 113 - 30 . 
Table 1: Species abundance in the Mesolithic layers of Kotias Klde

\begin{tabular}{|c|c|c|c|c|}
\hline & & NISP & $\%$ NISP & MNI \\
\hline Roe deer & Capreolus capreolus & 59 & 7.6 & 1 \\
\hline Red deer & Cervus elaphus & 58 & 7.5 & 2 \\
\hline Boar & Sus scrofa & 306 & 39.5 & 4 \\
\hline Brown bear & Ursus arctos & 103 & 13.3 & 4 \\
\hline Boar/bear & Sus-Ursus & 173 & 22.3 & \\
\hline Wolf/dog & Canis sp. & 3 & 0.4 & 1 \\
\hline Fox & Vulpes sp. & 3 & 0.4 & 1 \\
\hline Pine marten & Martes martes & 41 & 5.3 & 2 \\
\hline Porcupine & Hystrix sp. & 1 & 0.1 & 1 \\
\hline Aves & & 10 & 1.3 & 2 \\
\hline Fish & & 18 & 2.3 & 2 \\
\hline Total & & 775 & 100.0 & 20 \\
\hline
\end{tabular}


Table 2: Taphonomic observations for Kotias Klde faunal assemblage

\begin{tabular}{|c|c|c|c|c|c|c|}
\hline & & Roe deer & Red deer & $\begin{array}{l}\text { Wild } \\
\text { Boar }\end{array}$ & $\begin{array}{c}\text { Brown } \\
\text { bear }\end{array}$ & Total \\
\hline \multirow[t]{2}{*}{ NISP (excluding teeth) } & & 56 & 49 & 243 & 82 & 430 \\
\hline & $\mathrm{n}$ & 2 & 3 & 11 & 5 & 21 \\
\hline \multirow[t]{2}{*}{ Burned } & $\%$ & $4 \%$ & $6 \%$ & $5 \%$ & $6 \%$ & $5 \%$ \\
\hline & $\mathrm{n}$ & 0 & 4 & 5 & 3 & 11 \\
\hline Butchery marks & $\%$ & $0 \%$ & $8 \%$ & $2 \%$ & $4 \%$ & $3 \%$ \\
\hline \multicolumn{7}{|l|}{ Long bone shaft } \\
\hline \multirow[t]{2}{*}{ fragmentation NISP:MNE } & $\mathrm{n}$ & $23: 12$ & $18: 11$ & $24: 18$ & $3: 3$ & \\
\hline & $<50 \%$ & 6 & 8 & 11 & 1 & 26 \\
\hline Long bone shaft & $>50 \%$ & 4 & 3 & 7 & 3 & 17 \\
\hline \multirow[t]{3}{*}{ circumference } & $100 \%$ & 2 & 0 & 4 & 7 & 13 \\
\hline & $\mathrm{n}$ & 4 & 3 & 11 & 7 & 25 \\
\hline & of & 6 & 7 & 18 & 12 & 44 \\
\hline \multirow[t]{3}{*}{ Green fracture } & $\%$ & $66 \%$ & $42 \%$ & $61 \%$ & $58 \%$ & $56 \%$ \\
\hline & $\mathrm{n}$ & 13 & 12 & 18 & 22 & 65 \\
\hline & of & 0 & 0 & 0 & 1 & 1 \\
\hline \multirow[t]{2}{*}{ Weathered ( $\geq$ stage 2 ) } & $\%$ & $0 \%$ & $0 \%$ & $0 \%$ & $5 \%$ & $2 \%$ \\
\hline & $\mathrm{n}$ & 0 & 0 & 1 & 2 & 3 \\
\hline \multirow[t]{2}{*}{ Carnivore modifications } & $\%$ & $0 \%$ & $0 \%$ & $0 \%$ & $2 \%$ & $1 \%$ \\
\hline & $\mathrm{n}$ & 0 & 1 & 4 & 1 & 6 \\
\hline \multirow[t]{2}{*}{ Rodent Gnawing } & $\%$ & $0 \%$ & $2 \%$ & $2 \%$ & $1 \%$ & $1 \%$ \\
\hline & $\mathrm{n}$ & 0 & 0 & 2 & 1 & 3 \\
\hline \multirow[t]{2}{*}{ Root-marked } & $\%$ & $0 \%$ & $0 \%$ & $1 \%$ & $1 \%$ & $1 \%$ \\
\hline & $\mathrm{n}$ & 0 & 0 & 0 & 0 & 0 \\
\hline \multirow[t]{2}{*}{ Bleached } & $\%$ & $0 \%$ & $0 \%$ & $0 \%$ & $0 \%$ & $0 \%$ \\
\hline & $\mathrm{n}$ & 0 & 0 & 0 & 0 & 0 \\
\hline Abraded & $\%$ & $0 \%$ & $0 \%$ & $0 \%$ & $0 \%$ & $0 \%$ \\
\hline
\end{tabular}


Table 3: Summary of aging from teeth and bones of wild boar and brown bear from Kotias Klde

\begin{tabular}{lcccc} 
& Roe deer & Red deer & Wild Boar & Brown bear \\
\cline { 2 - 5 } Fetal/neonatal & 0 & 0 & 9 & 0 \\
Juvenile & 0 & 0 & 39 & 7 \\
Adult & 12 & 10 & 51 & 47 \\
Old adult & 0 & 0 & 0 & 0 \\
Aged NISP & 12 & 10 & 99 & 54
\end{tabular}


Figure 1: Map showing the location of Kotias Klde, Imereti region, Republic of Georgia

Figure 2: Skeletal part representation of brown bear (top) and boars (bottom) from Kotias Klde

Figure 3: Photo of selected bear bones from Kotias Klde 
Figure 1:

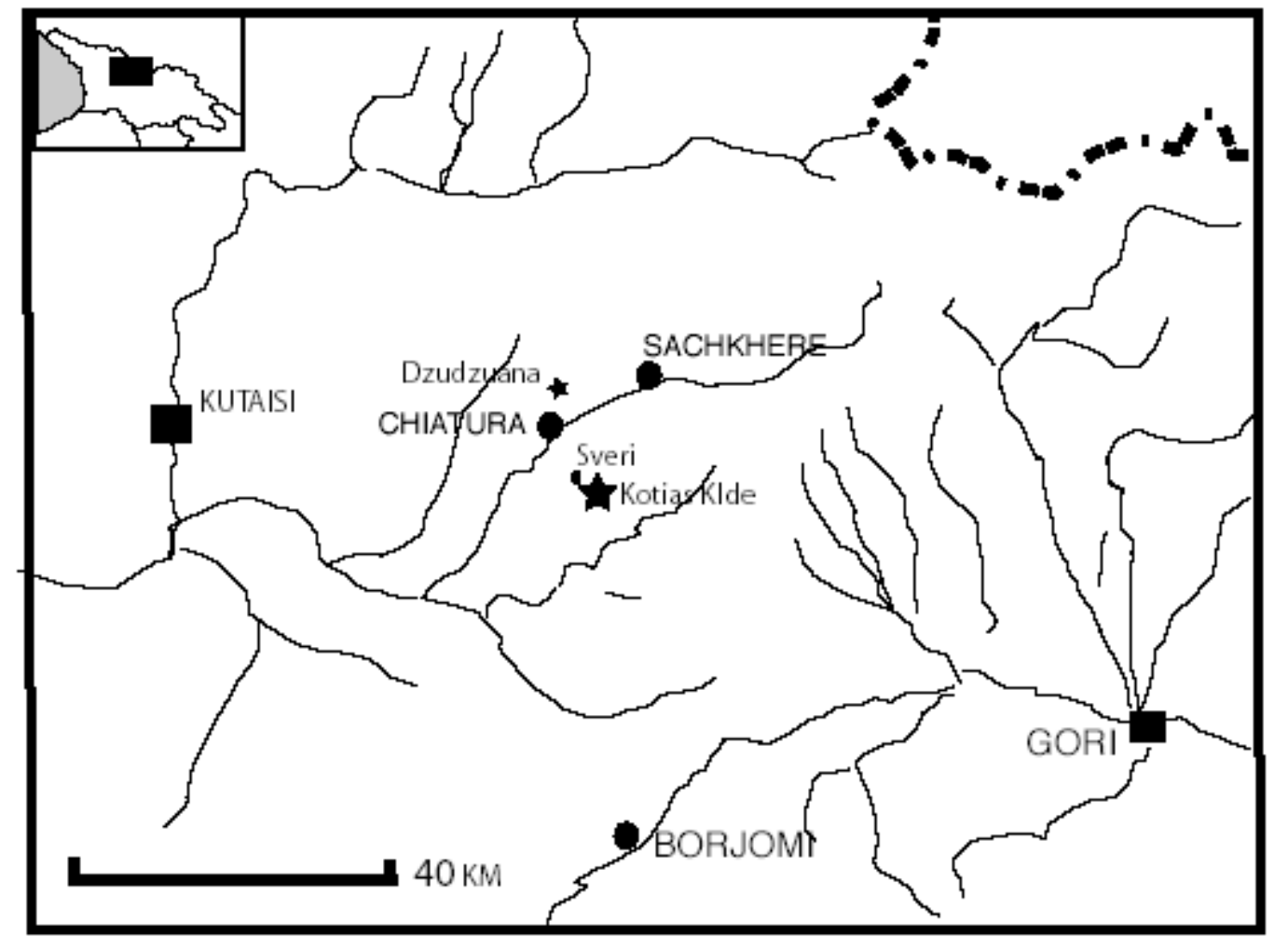


Figure 2:
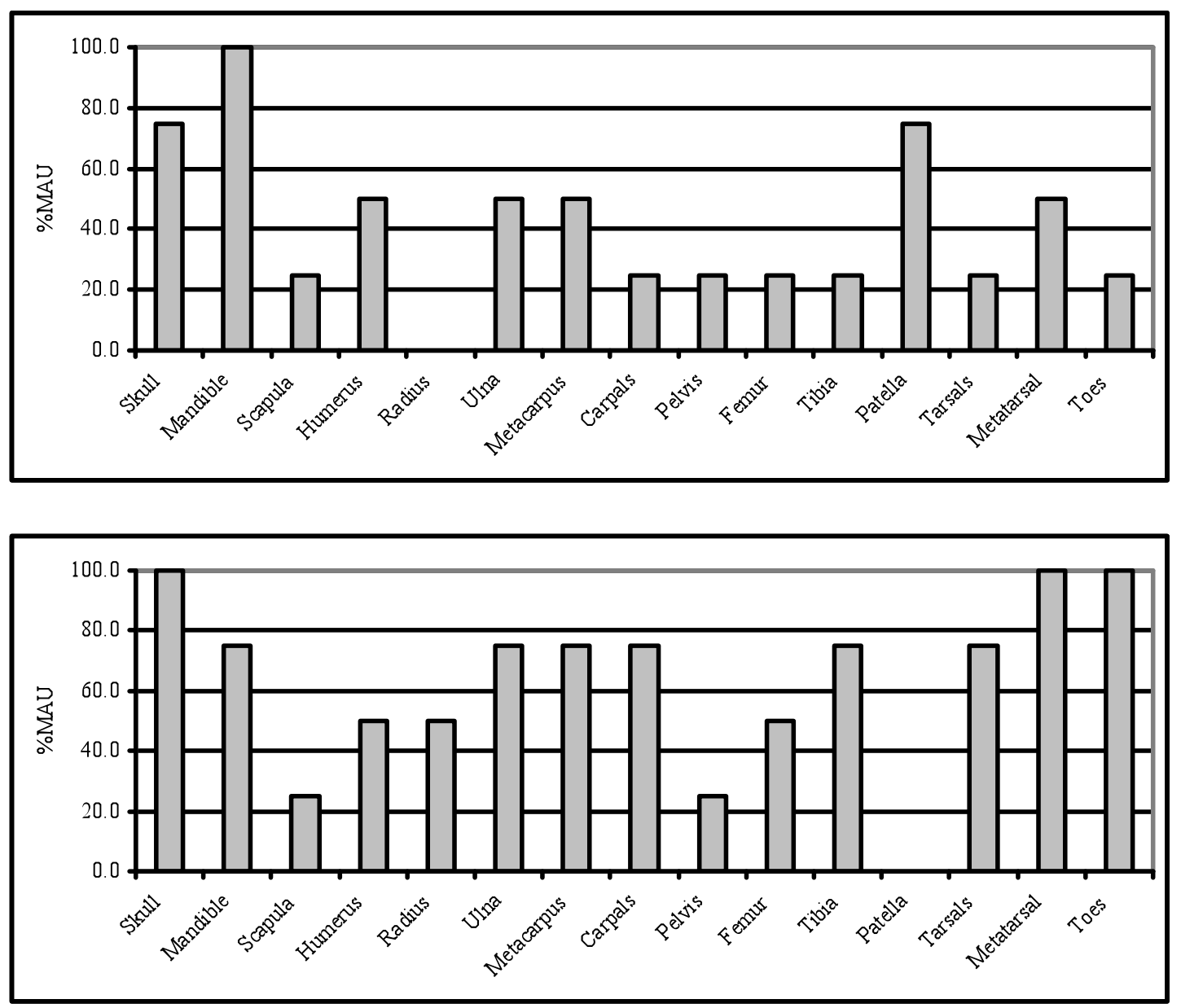
Figure 3:

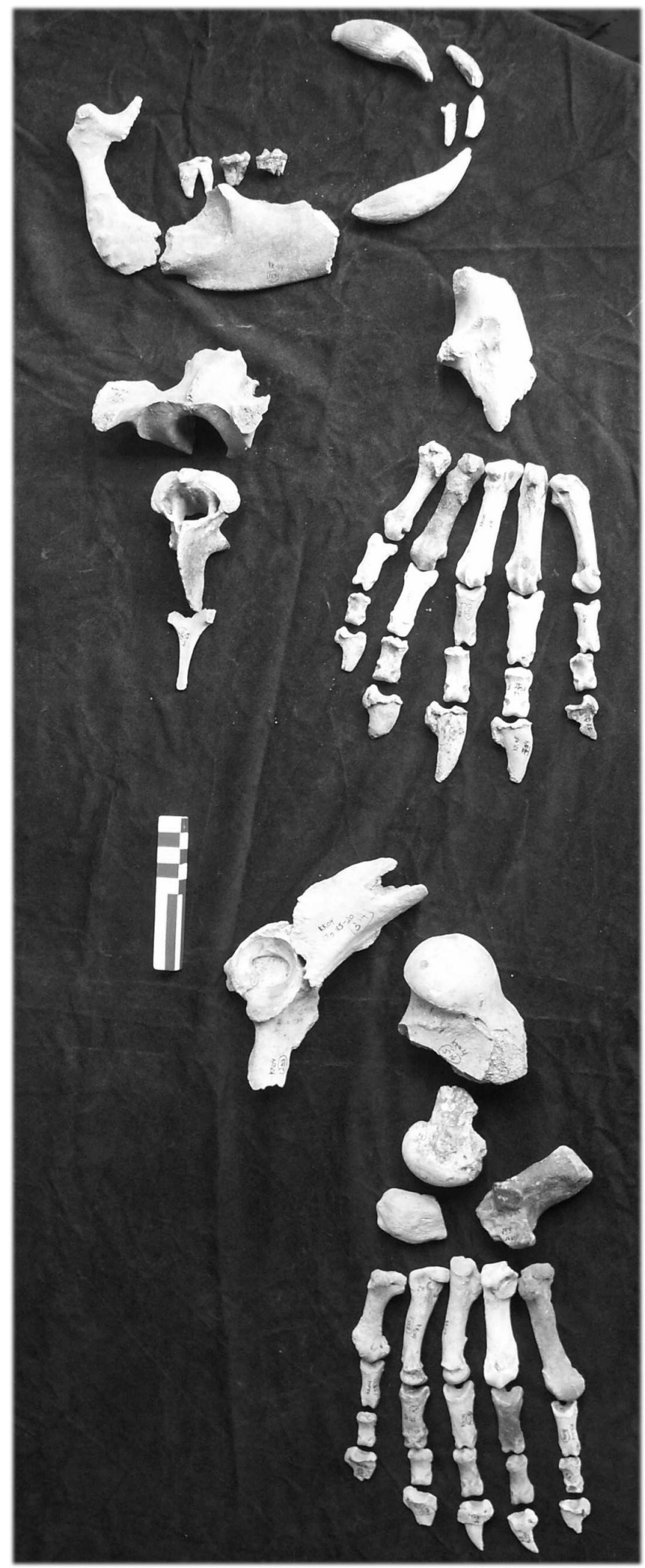


Appendix: NISP and MNE of wild boar, brown bear and boar/bear bone elements in the Mesolithic layer of Kotias Klde

\begin{tabular}{|c|c|c|c|c|c|c|c|}
\hline & & \multicolumn{2}{|c|}{ Sus scrofa } & \multicolumn{2}{|c|}{ Ursus arctos } & \multicolumn{2}{|c|}{ Sus/Ursus } \\
\hline & & NISP & MNE & NISP & MNE & NISP & MNE \\
\hline \multirow{8}{*}{ 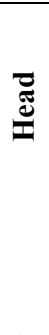 } & Skull fragment-occipital & 2 & 2 & 2 & 2 & & \\
\hline & Skull fragment-parietal & 1 & 1 & 1 & 1 & & \\
\hline & Skull fragment-petrosum & 1 & 1 & 1 & 1 & & \\
\hline & Mandible Condyle +fragment & 11 & 3 & 1 & 1 & & \\
\hline & Teeth & 63 & 61 & 21 & 20 & & \\
\hline & Vertebrae: Cervical & & & 1 & 1 & 10 & 8 \\
\hline & Vertebrae: Thoracic & 2 & 1 & & & 18 & 10 \\
\hline & Vertebrae: Lumbar & & & & & 26 & 16 \\
\hline \multirow{10}{*}{ 官 } & Vertebrae: caudal & 3 & 3 & & & 2 & 2 \\
\hline & Sacrum & 2 & 1 & & & & \\
\hline & Sternum & & & & & 2 & 2 \\
\hline & Clavicle & & & 1 & 1 & & \\
\hline & Rib fragment & & & & & 83 & \\
\hline & Scapula-glenoid-fossa & 1 & 1 & & & & \\
\hline & Scapula-sholder-blade & & & & & 4 & 1 \\
\hline & Humerus-proximal & 2 & 1 & & & & \\
\hline & Humerus-distal & 2 & 2 & 1 & 1 & & \\
\hline & Humerus-shaft & 3 & 2 & 1 & 1 & 3 & 1 \\
\hline \multirow{13}{*}{ 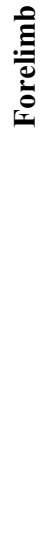 } & Radius-proximal & 2 & 1 & & & & \\
\hline & Radius-distal & 1 & 1 & & & & \\
\hline & Radius-shaft & & & & & 6 & 2 \\
\hline & Ulna-distal & 5 & 3 & 2 & 2 & & \\
\hline & Metacarpus-proximal & 1 & 1 & & & & \\
\hline & Metacarpus-complete & 9 & 9 & 9 & 9 & & \\
\hline & Carpal-magnum & 3 & 3 & & & & \\
\hline & Carpal-u & 5 & 5 & & & & \\
\hline & Acetabulum-ilium & 1 & 1 & & & & \\
\hline & Acetabulum-ischium & & & 1 & 1 & 1 & 1 \\
\hline & Other pelvic fragments & & & & & 5 & 2 \\
\hline & Femur-distal & 4 & 2 & & & & \\
\hline & Femur-shaft & 2 & 1 & & & 4 & 1 \\
\hline \multirow{11}{*}{ 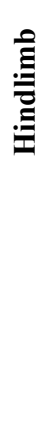 } & Tibia-proximal & 2 & 2 & 1 & 1 & & \\
\hline & Tibia-distal & 5 & 5 & & & & \\
\hline & Tibia-shaft & 1 & 1 & & & 7 & 3 \\
\hline & Patella & & & 3 & 3 & & \\
\hline & Astragalus & 2 & 2 & 1 & 1 & & \\
\hline & Calcaneum & 9 & 8 & 1 & 1 & & \\
\hline & central-4th-tarsal & 3 & 3 & 1 & 1 & & \\
\hline & Metatarsus-proximal & 12 & 12 & 3 & 3 & & \\
\hline & Metatarsus-complete & 4 & 4 & 8 & 8 & & \\
\hline & Metatarsus-shaft & 2 & 2 & & & & \\
\hline & Phalanx 1 & 35 & 26 & 17 & 17 & 1 & 1 \\
\hline \multirow{4}{*}{$\stackrel{\mathscr{\Xi}}{\mathscr{E}}$} & Phalanx 2 & 54 & 45 & 12 & 12 & & \\
\hline & Phalanx 3 & 28 & 28 & 10 & 10 & & \\
\hline & Metapod condyle & 21 & 21 & 4 & 4 & & \\
\hline & Metapod-shaft & 2 & 1 & & & 1 & 1 \\
\hline & NISP & 306 & 209 & 103 & 86 & 173 & 51 \\
\hline
\end{tabular}

